Puheenvuro

\title{
Vaikuttaako tiede politiikkaan?
}

\section{PEKKA PUSKA}

Yhteiskunnallinen keskustelu ja päätöksenteko heijastavat tänä päivänä monenlaisia arvoja ja virtauksia. Terveys ja hyvä elämä ovat aivan keskeisiä. Myös kaupallisuus leimaa jokapäiväistä elämää voimakkaasti. Samalla kun korostetaan yksilön vapauksia, painotetaan myös yhteisvastuun ja sosiaalisen huolenpidon tarpeita.

Tieteellisellä tutkimuksella ja asiantuntijatiedolla on vahva sananvalta. Puheissa korostetaan, kuinka yhteiskunnallisen päätöksenteon tulisi pohjautua tutkittuun tietoon ja tieteelliseen näyttöön. Mutta elävässä elämässä yhteiskunnallisen päätöksenteon taustalla on moninaisia tekijöitä ja tieteen yhteys poliittisen päätöksentekoon on varsin monitahoinen prosessi.

\section{MITÄ TIETEELLISELLÄ NÄYTÖLLÄ TARKOITETAAN?}

Terveyspolitiikassa sanotaan usein, että poliittisen päätöksenteon tulee pohjautua tieteelliseen näyttöön. Mutta mitä tieteellisellä näytöllä tarkoitetaan? On olemassa kovin monen tason näyttöä. Sitä kuvaa esimerkki tautien ehkäisyohjelmaa koskevasta tieteellisestä näytöstä (kuvio 1).

\section{Taudin etiologia}

(kausaaliset riskitekijät)

Ehkäisykeinot

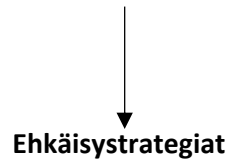<smiles>CCCCCC</smiles>

Toteutus
Vahva evidenssi

Hyvä evidenssi

Paljon näyttöä

Politiikkaa

Kuvio 1. Tautien ehkäisyohjelman päätöksenteon tausta 


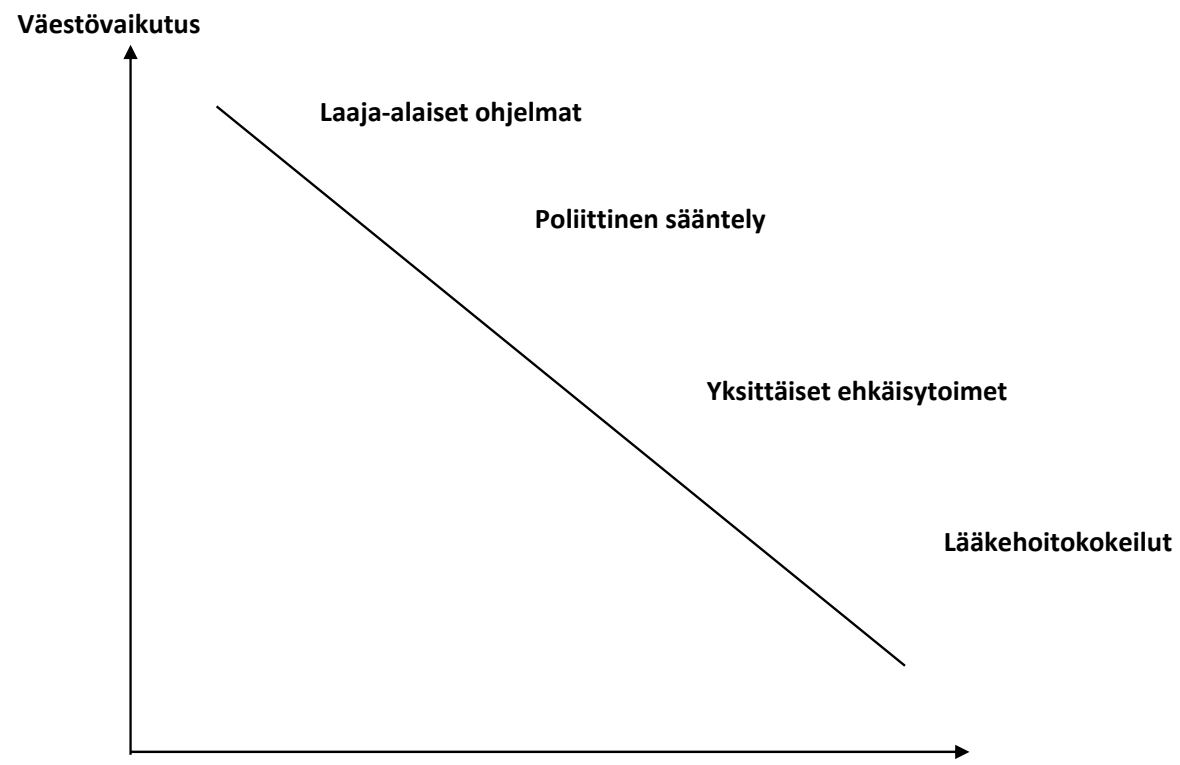

Evidenssin voimakkuus

Kuvio 2. Evidenssi ja väestötason vaikutus

Esimerkiksi sepelvaltimotaudin, tyypin 2 diabeteksen tai monien syöpien etiologiasta on hyvin vankka tieteellinen näyttö. Myös monien yksittäisten interventiomenetelmien vaikutuksista on paljon vahvaa näyttöä. Mutta kun mennään laaja-alaisempiin väestötason ehkäisyohjelmiin ja poliittisiin päätöksiin - ja vielä hyvin erilaisissa olosuhteissa - on kovan tieteellisen näytön antaminen hankalampaa, vaikka voidaan kuvata erilaisia kokemuksia. Tämä monitasoisuus heijastuu poliittisessa keskustelussa.

Toinen tärkeä asia on evidenssin merkitys suhteessa väestötason vaikutuksiin. Mitä rajatummasta interventiosta on kysymys, sen helpompi on saada pätevä näyttö. Esimerkiksi yksittäisen lääkkeen kohdalla voidaan kaksoissokkokokeella saada hyvin pitävä tieteellinen näyttö siitä, kuinka lääke on tilastollisesti erittäin merkittävästi tehokkaampi kuin vertailulääke tai placebo. Toisaalta tällaisen "pätevän näytön" saaminen laaja-alaisesta terveyden edistämisen interventiosta tai politiikasta on hankalaa tai mahdotonta.

Kuitenkin, ajatellen kansanterveydellistä vaikutusta (population impact) laaja-alaisen intervention potentiaali sekä vaikutuksen että kustannusvaikutuksen suhteen voi olla huimasti suurempi kuin rajallisen lääkeintervention tai muun hoito- intervention, jota koskevat tutkimustulokset sitä paitsi koskevat ahtaasti ottaen vain tutkimuksen rajaamaa kohdejoukkoa. (Kuvio 2) Tiukan evidenssin korostaminen eräällä tavalla vahvistaa lääkeinterventioita suhteessa terveyden edistämisen tai poliittisen sääntelyn interventioihin.

\section{EVIDENSSIN OSUUS PÄÄTÖKSENTEOSSA}

Lääketieteen ja terveysalan asiantuntijat ovat usein turhautuneita siitä, että kova terveysevidenssi ei ratkaise päätöksenteossa. Tällöin on kuitenkin ymmärrettävä, että yhteiskunnallisessa päätöksenteossa terveysevidenssi on vain eräs, vaikka ilahduttavan usein tärkeä tekijä. Taustalla on paljon laajempi kokonaisuus, jossa kuitenkin toivottavasti terveysevidenssin tulisi saada riittävä painoarvo. Terveysnäytön lisäksi on muunlaista evidenssiä, esimerkiksi talouden realiteetit, taloudelliset vaikutukset, työllisyys- ja ympäristövaikutukset ja niin edelleen.

On myös muistettava, että poliittiseen päätöksentekoon vaikuttavat paljon arvot. Kun tupakkateollisuus kysyi aikoinaan, että mitä näyttöä on siitä, että tupakkamainonnan kielto vähentäisi tupakointia, voitiin esittää vastakysymys: Onko eettisesti oikein mainostaa tuotetta, joka tappaa useamman kuin joka toisen pitkäaikaiskäyttäjänsä? 
Päätöksentekijän oman arvomaailman ohella hyvin ratkaisevaa on väestön mielipide. Vaikeissa asioissa poliittiset päätöksentekijät toki huomioivat tutkitun tiedon, mutta vielä tärkeämpi on väestön (s.o. äänestäjien) mielipide. Sitä kutsutaan demokratiaksi.

Näin ollen poliittiseen päätöksentekoon vaikutetaan toki paljon esittelemällä poliitikoille suoraan sitä, mitä tieteellinen tutkimus asiasta sanoo. Mutta vielä paljon tärkeämpi on epäsuora vaikutus väestön mielipiteen kautta. Tästä tullaan kysymykseen siitä, miten tutkittua tietoa saadaan väestössä perille ja omaksutuksi. Tämä liittyy yhteiskunnalliseen keskusteluun, jossa elinkeinoelämä ja terveyspolitiikka usein törmäävät.

\section{TOTEUTUSKUILU ("IMPLEMENTATION GAP")}

Puhuttaessa erilaisten kansanterveydellisten ohjelmien ja strategioiden toteutuksen ongelmista korostetaan yleensä niiden tieteellistä pohjaa ja evidenssitaustaa. Esimerkiksi kansantautien ehkäisyohjelmia on laadittu parhaan tiedon pohjalta ja niin, että niissä on monia evidenssiin perustuvia toimenpidesuosituksia.

Tällaisia strategioita ovat globaalilla tasolla esimerkiksi WHO:n strategia tarttumattomien tautien ehkäisystä ja torjunnasta sekä tähän pohjautuvat WHO:n ravinto-liikunta -strategia ja WHO:n strategia haitallisen alkoholin käytön vähentämiseksi. Näistä aiheista on vastaavia Suomen ja muiden maiden viranomaisten strategioita ja toimenpideohjelmia. Myös isoilla terveysalan asiantuntijajärjestöillä on vastaavia ohjelmia.

Nämä strategiat on usein valmisteltu varsin perinpohjaisessa prosessissa ja tutkimusnäyttöön pohjautuen. Niiden osittaisellakin toteutuksella olisi usein huomattava myönteinen vaikutus väestön terveyteen. Kuitenkin kovin monen ohjelman ja strategian toteutus on jäänyt vaatimattomalle tasolle - joskus jopa "hyllylle pölyttymään”.

Tätä tilannetta on kuvattu termillä toteutuskuilu ("implementatin gap"). Eli väestön terveyden edistämisen ongelma ei ole, etteikö olisi näyttöön perustuvia keinoja tai toimenpiteitä vaan se, miten ne voidaan elävässä elämässä ja poliittisessa päätöksenteossa toteuttaa.

Tämän toteutuskuilun syitä on monesti pohdittu. Niitä on hyvin moninaisia:
- taloudelliset vasta-argumentit,

- muut kuin terveysvaikutukset,

- kaupallinen vastustus ja lobbaus,

- yleinen muutosvastarinta ja yleinen mielipide sekä

- kulttuurimuutosten hitaus.

Samalla tavalla on pohdittu sitä, minkä tyyppisillä toimenpiteillä tätä muutoskuilua voisi vähentää. Tutkimuksen osalta sen tulisi terveysevidenssin lisäksi suuntautua ongelman erilaisiin taustatekijöihin (käyttäytymistieteellinen, yhteiskuntatieteellinen, taloustieteellinen ym. tutkimus) sekä tarvittavan muutosprosessin determinanttien ymmärtämiseen. Klassista tupakkaesimerkkiä käyttäen ei riitä, että tutkitaan, miksi ihmiset tupakoivat. Kun valtaosa tupakoivista haluaisi lopettaa, on tärkeää tutkia lopettamisen ja väestön tupakoinnin vähentämisen keinoja.

Tutkitun tiedon suhteen tärkeää ei ole vain tiedon olemassaolo vaan tämän tiedon hyvä välittäminen niin päätöksentekijöille kuin väestölle. Tässä tulevat kysymykseen tiedon levittämisen kanavat ja sen institutionaalinen pohja, kuten valtion laitosten ja terveysalan suurten järjestöjen asema ja mahdollisuudet. Myös median rooli on tärkeä muutoskuilun vähentämisessä.

Hyvin merkittävä tutkimustieto koskee myös trendejä. Mediaa ja väestöä kiinnostavat tavattomasti tapahtunut kehitys: myönteistä tai kielteistä. Se mitä seurataan, vaikuttaa myös päätöksiin. On vanha sanonta, että "mitä mitataan, siitä puhutaan".

Ohjelmien toimeenpanon kannalta on myös korostettu, että ongelmien ja tutkimusnäytön monitahoisuudesta huolimatta isojen vaikutusten kannalta pitäisi keskittyä hyvin pieneen määrään olennaisia strategisia tavoitteita periaatteella "less is more".

Toteutuskuilun vähentämisessä on poliittisiin päätöksiin vaikuttamisen keinoina listattu $\mathrm{mm}$. seuraavia:

- rationaaliset argumentit (terveys, talous, muut),

- median käyttö poliittisten päätösten edistämiseksi,

- vasta-argumenttien käsittely ja kumoaminen,

- järjestöjen käyttö painostusryhminä,

- väestön (äänestäjien) mobilisointi,

- emotionaalisten tekijöiden ja tarinoiden käyttö sekä

- kansainväliset esimerkit. 


\section{TERVEYSPOLITIIIKKA JA ELINKEINOPOLITIIIKKA - YHTEENTÖRMÄYSTÄ VAI SYNERGIAA?}

Kaupallisuus vaikuttaa elintapoihin sekä ympäristöön ja sitä kautta terveyteemme yhä enemmän. Näin on sekä hyvässä että pahassa. Elintarvikepuolella kansalaisten kiinnostus terveyteen ja viime aikoina myös kestävään kehityksen tuotteisiin on suuresti vaikuttanut myönteiseen tuotekehitykseen ja sitä kautta kansanterveyteen.

Kaupallinen elinkeinoelämä pelaa markkinatalouden säännöillä, ja yritysten tehtävänä on tuottaa taloudellista voittoa. Sellaiset alat, joiden tulot perustuvat epäterveellisten tuotteiden valmistukseen ja myyntiin, pyrkivät ylläpitämään tulojaan itselleen sopivalla viestinnällä, mainonnalla ja vaikuttamalla lobbauksella poliittiseen päätöksentekoon. Tyypillisiä aloja, joilla törmäykset terveyspolitiikan kanssa tapahtuvat ovat tupakkateollisuus, alkoholiteollisuus ja eräät elintarviketeollisuuden alat - viime aikoina erityisesti virvoitusjuomateollisuus.

Tupakkateollisuus on viime vuosikymmenien kuluessa joutunut sääntelyssä yhä ahtaammalle. Sen seuraukset näkyvät lainsäädännön kiristymisenä kaikkialla maailmassa ja meillä muun muassa tupakoinnin tavattomana vähenemisenä. Tämän myönteisen käänteen liikkeelle panevana voimana on ollut tieteellinen tutkimus, joka yli viisi vuosikymmentä sitten osoitti sitovasti tupakan keskeisen osuuden keuhkosyöpäepidemia taustalla.

Tämä esimerkki osoittaa myös, kuinka hitaasti tutkittu tieto voi vaikuttaa kääntämään yhteiskunnallista kehitystä. Vasta jatkuva lisätutkimus, laaja valistus sekä poliittinen päätöksenteko lainsäädännön muodossa ovat yhdessä vaikuttaneet, ensin länsimaissa ja nyt maailmanlaajuisesti. Kun näyttö tupakan globaaleista valtavista terveyshaitoista vahvistui, saatiin vuonna 2003 hyväksytyksi maailmanlaajuinen tupakoinnin torjunnan konventio (FCTC), jolla yhdessä EU:n tupakkadirektiivin kanssa on ollut huomattava lisävaikutus.

Alkoholiteollisuus on tupakan jälkeen joutunut viime vuosina poliittisen keskustelun kohteeksi johtuen tutkimuksen osoittamista suurista kansanterveydellisistä, sosiaalisista ja kansantaloudellisista haitoista. Vuoden 2017 keskustelu ja poliittinen päätöksenteko uudesta alkoholilaista eduskunnassa heijasti hyvin selvästi törmäystä toisaalta tutkitun tiedon, yhteisvastuun ja heikompien puolustamisen ja toisaalta kaupallisten intressien ja yksilöllisyyden välillä.

Myös alkoholin kohdalla kansainvälinen vaikutus on suurta. Kansainvälinen alkoholiteollisuus on viinialaa lukuun ottamatta hyvin keskittynyttä. Suuret alkoholijätit pystyivät vuosikausia estämää WHO:ssa globaalin alkoholistrategian valmistelun ja hyväksymisen.

Ravinnon suhteen asia on vielä monitahoisempi kuin tupakan ja alkoholin kohdalla. Ravinto on monimutkainen kokonaisuus, jossa on kysymys muun muassa suolasta, sokerista, rasvan laadusta, kuidusta. Takavuosien rasvasota, jota on jälkeenpäin paljonkin analysoitu, on hyvä esimerkki yhteentörmäyksestä. Vahva ja monipuolinen kansainvälinen ja kotimainen tutkittu terveystieto oli ratkaisevassa asemassa siinä, että yhteentörmäys vähitellen päätyi terveyspuolen voittoon.

Kansainvälisellä tasolla samanlaista yhteentörmäystä on tapahtumassa erityisesti sokerin, palmuöljyn ja suolan kohdalla. Lihavuuden yleistyminen maailmassa ja erityisesti lasten parissa on kiinnittänyt tutkimushuomiota erityisesti sokeripitoisiin tuotteisiin. Vaikka lasten ja nuorten lihomisen syyt ovat monitahoiset, tutkimus on selvästi osoittanut juuri virvoitusjuomien osuuden lasten ylipainossa. Tähän liittyvää tutkimustietoa alan jättiteollisuus on pyrkinyt eri tavoin torjumaan tai vähättelemään.

Paitsi teollisuus myös kauppa on kiintoisassa asemassa. Se pyrkii lisäämään myyntiään ja talouttaan saamalla hyllyilleen enemmän lääkkeitä ja alkoholituotteita. Toisaalta terveyspuolella suhtaudutaan tähän hyvin varauksellisesti. Korostetaan, että nämä eivät ole tavallisia tuotteita, joita pitäisi myydä markkinaehtoisesti tuhansista kaupoista, kioskeista ja huoltoasemilta. Tässä keskustelussa haastetaan myös tutkimusevidenssiä, muun muassa saatavuuden vaikutuksesta.

Kun terveysasioilla on kasvava merkitys ostopäätösten kannalta, elinkeinoelämä pyrkii hyödyntämään tutkimustuloksia ja vetoamaan niihin kaupallisten intressiensä kannalta. Silloin kun on kysymys oikeista ja kansanterveydellisistä tosiasioista tällainen win-win tilanne on ilman muuta hyödyllinen. Tähän liittyvä yhteistyö ja niin sanottu public-private -partnership voi myös olla hyödyllistä. Usein ongelmana on kuitenkin, että suurten yritysten painoarvo on niin paljon suurempi ja hanke voi koskea vain rajoit- 
tunutta osaa yrityksen kokonaismarkkinoinnista - joskus voidaan puhua jopa niin sanotusta "kasvojen pesusta".

Positiivinen esimerkki sääntelystä oikean tiedon suuntaan on EU-tason direktiivi elintarvikkeiden terveysväittämistä. Näillä säädöksillä sallitaan tieteelliseen tutkimustietoon pohjautuvien kriteerien perusteella terveysväitteet, jotka perustuvat tutkimusnäyttöön. Perusteettomat väitteet taas kielletään.

Eräs viime vuosien terveyspolitiikan ja elinkeinopolitiikan konkreettinen törmäysala viime vuosina ovat olleet niin sanotut haittaverot. Veroilla vaikutetaan haitallista kulutusta vähentävästi, mutta samalla valtio saa lisää kaivattuja verotuloja. Elinkeinoelämä lobbaa voimakkaasti näitä vastaan. Se pyrkii kiistämään tutkimusnäytön hinnan vaikutuksesta kulutukseen ja ohjaamaan keskustelua muihin seikkoihin.

\section{MAINONTA JA LOBBAUS TUTKIMUSNÄYTTÖÄ VASTUSTAMASSA}

Mikäli tutkimusnäyttö ei ole yritysten tuotteille myönteistä, pyritään liiketoimintaa ylläpitämään mainonnalla, markkinoinnilla ja sääntelypolitiikkaa lobbaamalla. Suurten yritysten kohdalla ja kansainvälisessä mittakaavassa puhutaan todella valtavista summista. Esimerkiksi Coca Colan markkinointibudjetti on lähes kaksinkertainen Maailman terveysjärjestön WHO:n budjettiin verrattuna. Vaikka tieteellisen tutkimuksen näyttöä ja terveysasioita arvostetaan, voidaan valtavilla resursseilla, jopa tieteellisesti kehitetyn markkinoinnin avulla, sivuuttaa paljon tutkittua terveystietoa.

Kaupallisten yritysten lobbaus niin meillä kuin muualla perustuu useammanlaiseen toimintaan. Siinä käytetään muun muassa

- erilaista yhteydenpitoa päätöksentekijöihin,

- kampanjatukea,

- samanmielisten koalitioiden rakentamista,

- erilaisia lehdistösuhteita,

- yleisen mielipiteen mobilisointia ja

- tuetaan myönteisiä kansalaishankkeita taloudellisesti.

Tällä toiminnalla pyritään kumoamaan terveyspuolen pyrkimykset ja tutkimusnäyttö - tai ainakin nakertamaan sitä eri tavoin. Kaupallisilla toimijoilla on toki yhteiskunnassa normaali sananvapaus, mutta ongelmana on, että elinkeinoelämällä on usein niin moninkertaiset resurssit.
Terveyspuolen ja tutkimuksen etuina ovat toki parempi uskottavuus ja tärkeä terveyssanoma.

Lobbauksessa käytetyt viestit ovat kansainvälisesti katsoen ja hyvinkin erilaisten tuotteiden kohdalla huomattavan samankaltaiset:

- korostetaan yksilön valinnanvapautta,

- korostetaan työllisyysargumentteja,

- viitataan holhoukseen ja terveysterrorismiin,

- vedotaan tunteisiin (esim. Marlboro mies),

- kyseenalaistaan vastustajien motiivit,

- käytetään somessa trolleja,

- tutkimustulosten laajasta kentästä hyödynnetään itselle sopivia osatuloksia ja rahoitetaan "omia" tutkimuksia,

- elintarvikkeiden kohdalla viitataan vain yhteen ravintokomponenttiin unohtaen koko ravintoprofiilin.

\section{MISSÄ TIEDE VOI VAIKUTTAA?}

Julkinen mielenkiinto ja tutkimuksen edustajat heräävät usein vasta, kun jostakin asiasta käydään näyttävää eduskuntakeskustelua. On kuitenkin ymmärrettävä, että vaikka eduskunnassa tehdään ratkaisevat päätökset, se on ketjussa viimeinen paikka vaikuttaa.

Asiat tuo eduskuntaan maan hallitus. Enemmistöhallituksen esityksiin eduskunnassa on hyvin vaikea vaikuttaa. Tärkeämpi on vaikuttaa hallituksen päätöksiin, ja mieluiten vielä ennen sitä eli ministeriöiden aloitteisiin, valmisteluun ja esityksiin.

Aloitteet tulevat yhteiskunnan eri tahoilta, niin elinkeinoelämältä kuin järjestöiltä ja eri laitoksilta. Aloitteiden pohjalta ministeriöt ryhtyvät usein valmistelutyöhön, jossa tiedemaailman edustajien vaikutusmahdollisuus on tärkeä. Sen jälkeen seuraa esitysten lausuntovaihe, joka on usein hyvin ratkaiseva.

Isoissa linjakysymyksissä hallitusohjelma on keskeisessä asemassa. Sen vuoksi eduskuntavaaleja ennen ja heti se jälkeen, tärkeitä ovat hallitusohjelmaa koskevat keskustelut, yleinen mielipide ja puolueiden valmistelutyö.

\section{YLIOPISTOT JA TUTKIMUSLAITOKSET - TIETEELLISEN TIEDON LINNAKKEET!}

Kun tieteen ja tutkitun tiedon vaikutus poliittiseen päätöksentekoon kansalaisten parhaaksi on edellä kuvatulla tavalla hyvin monitahoinen vyyhti ja kun pidämme tärkeänä tutkimusnäyttöön perustuvaa politiikkaa, on tieteellisen tiedon 
institutionaalinen pohja yhteiskunnassa tärkeä. Sen pohjan ovat kautta aikojen muodostaneet yliopistot ja tutkimuslaitokset.

Niiden työtä ohjaavat parhaimmillaan puolueettoman tieteellisen tutkimuksen periaatteet ja vapaa tieteellinen keskustelu. Valtiovalta voi ja saa toki rahoittaa "poliittisesti tärkeänä pidettyä” tutkimusta, mikä tietyiltä osin on ymmärrettävää ja hyödyllistä. Se ei kuitenkaan saa vähentää yliopistojen tieteellistä ja toiminallista autonomiaa. On tärkeää, että yliopistoja ei alis- teta liikaa yhteiskunnan kulloisillekin poliittisille pyrkimyksille, vaan että ne pysyvät vapaa tieteen ja sivistyksen linnakkeina - esimerkiksi kuten Turun yliopiston päärakennuksen seinässä oleva tunnettu tunnuslause sanoo: "Vapaan kansan lahja vapaalle tieteelle"!

\section{Pekka Puska}

LKT, VTM, professori

kansanedustaja

emeritus pääjohtaja THL 